\title{
A estratégia da urgência: considerações sobre O cheiro do ralo, de Lourenço Mutarelli
}

Ivana Ferigolo Melo ${ }^{1}$

Ando muito completo de vazios.

Meu órgão de morrer me predomina.

Manuel de Barros

Socorro

não estou sentindo nada nem medo, nem calor, nem fogo

não vai dar mais pra chorar nem pra rir.

Arnaldo Antunes

Quem acompanha a produção narrativa brasileira das últimas décadas do século XX e início do XXI logo notará que um dos traços presentes em muitas obras (embora isso não seja uma constante) é a preponderância do que se poderia chamar de uma urgência na forma de contar. Urgência que viabiliza, entre outras coisas, a rápida leitura dessas narrativas e gera, em um primeiro momento, a impressão de se tratar de obras carentes de densidade e, por isso, pouco inclinadas a desencadear, no receptor, profundos processos de reflexão e questionamento. Essa urgência, por exemplo, dá o tom a todas as obras de João Gilberto Noll, fazendo-se visível também em romances como Estive em Lisboa e lembrei de você, de Luiz Ruffato, e O cheiro do ralo, de Lourenço Mutarelli, para citar algumas. Na opinião de Tânia Pellegrini (2008), essa tendência à concisão e à rapidez do narrar começa a se projetar no Brasil na década de 1970 e vem ganhando muito espaço, uma vez que é estimulada por um mercado que, visando principalmente ao lucro, vê nas narrativas breves, de recepção e descarte rápidos, produtos simbólicos muito favoráveis à venda e ao consumo em maior escala. Nas palavras da autora:

\footnotetext{
${ }^{1}$ Doutora em Letras e professora da Universidade do Estado do Mato Grosso (Unemat), Tangará da Serra, MT, Brasil. (Dorcid.org/0000-0003-0733-1024. E-mail: ivanaferigolo@gmail.com
} 
Se grande parte da literatura produzida nos anos 70 ainda se caracteriza pela crença no poder da palavra, na sua "função" potencial de transformar as estruturas sociais, de revelar a "realidade brasileira" injusta e desigual, inclusive no campo, e também por um certo teor artesanal da sua fatura, que ainda comportava experimentalismos formais individualizantes, a das décadas subsequentes terá muito mais afinidades com a pressa do mercado [...]. Assiste-se, também, ao surgimento da busca de inserção no mercado, inclusive internacional, o que implica transformações significativas do código estético-literário, que aos poucos incorpora como naturais - com as habituais exceções - descuidos, mesmices, obviedades e redundâncias na fatura, em busca de leitores cada vez mais apressados e interessados nos derivativos que a televisão oferece (Pellegrini, 2008, p. 20).

É inquestionável, por um lado, a constatação de Pellegrini. A urgência na forma de contar e a brevidade das narrativas se ajustam mais facilmente às expectativas de um público apressado, a um filão de leitores (muito comum, principalmente, nas grandes cidades) que, ocupadíssimo pelas excessivas exigências de uma sociedade cujo imperativo é produzir e consumir massivamente e interpelado constantemente pelos mass media, vê o tempo necessário à leitura cadenciada, lenta e propicia à reflexão profunda escapar ou comprimir-se.

Há que se considerar, porém, que o fato de uma narrativa servir à leitura rápida não implica necessariamente que ela oblitera o desencadeamento de processos reflexivos. O leitor, a qualquer momento, poderá fechar o livro, deter-se em fragmentos, elucubrar, rememorar, fazer relações entre o universo narrado e sua existência, entre as sensações que ele lhe desperta e as que registra ou registrou em seu horizonte existencial. Tudo isso consiste em um tipo de atividade reflexiva. Desde essa perspectiva, a rapidez na forma de contar e a concisão do livro poderão ser enfocadas também como estratégias compositivas eficientes na tática de angariar receptores apressados: aqueles que poderiam desistir da leitura antes mesmo de abrir o livro em função de seu volume e extensão ou logo nas primeiras páginas ao constatar uma exigência excessiva de tempo para ser finalizado.

E não há como negar: esses leitores carentes de tempo são os mais abundantes no frenético mundo em que vivemos. Na atual sociedade, 
em virtude da predominância de um modelo de produção e consumo excessivos, da circulação intensa e rápida de informações dos mais diversos tipos, de contatos e trocas instantâneos estabelecidos, principalmente, pelas redes sociais, da exigência no desempenho simultâneo de tarefas múltiplas e variadas, mais do que nunca, os homens têm restringidas, quando não eliminadas, as possibilidades de sentar sem pressa para ler e desfrutar de obras formalizadas mediante elaborados artifícios de linguagem. O que definiria o ritmo humano da atualidade seria, portanto, a acentuação de um estado de pressa que já se manifestava no início do século XX, e que Benjamin detectava ao retomar o pensamento de Paul Valéry. Dizia o autor que, na sociedade atual (década de 1930), o homem "não cultiva mais aquilo que não pode ser abreviado" (Valéry, 1960, p. 1.244 apud Benjamin, 2012, p. 223).

Atento às possíveis alterações sensíveis registradas pelos homens em decorrência da ação do modelo social e de vida no qual se inscreviam, Valéry e Benjamin sinalizavam uma possível necessidade de adaptação das produções artísticas à voragem intrínseca às formas de vida e às sensibilidades que se projetavam (e que perduram até hoje, só que de forma mais acentuada). É essa adaptação que parecem registrar obras como as de João Gilberto Noll ou $O$ cheiro do ralo, de Mutarelli, entre outras. A brevidade, a rápida leitura que as caracteriza, tende a se apresentar, assim, como estratégia compositiva (adaptação estrutural) encontrada pela narrativa para alcançar e conquistar um sensório humano moldado pela pressa, tão característico daqueles que habitam um meio em que o tempo é o elemento mais precioso e precisa ser "melhor gasto". ${ }^{2}$

Isso não quer dizer, porém, que tais produções não agreguem potencial de denúncia, capacidade de impactar ou de provocar reflexão. Tal potencial, porém, parece decorrer da própria urgência de contar que lhes é característica. A rapidez faz com que elas não veiculem imagens densas e profundas dos mundos a que se propõem representar, forçando o receptor a sentir a angústia e o espanto oriundos do contato com circunstâncias rarefeitas, imprecisas, incertas e voláteis, muito semelhantes àquelas que o leitor apressado poderá experimentar em seu turbulento e caótico

\footnotetext{
${ }^{2} \mathrm{O}$ tempo passa a ser a menina dos olhos porque a alta produção está diretamente relacionada à capacidade humana de otimização do tempo, de seu máximo uso, da realização de muitas e múltiplas tarefas no menor intervalo possível.
} 
cotidiano. Ditas narrativas, ao contrario do que tencionava fazer o romance que se convencionou chamar de moderno, ${ }^{3}$ parecem se propor replicar as velozes formas de vida típicas da atualidade, convidando o leitor a perceber e a sentir os efeitos de uma existência pautada numa celeridade vital intensa e desencadeadora, na maioria das vezes, da alienação ou automatização dos indivíduos.

Isso é o que tende a ocorrer na narrativa que aqui será objeto de análise - $O$ cheiro do ralo, de Lourenço Mutarelli -, no sentido de sinalizarmos que, na velocidade/urgência narrativa que lhe é sobressaliente, encontra-se um de seus traços estruturais mais relevantes e responsáveis pela representação de formas de vida aceleradas e deflagradoras de um estado de torpor existencial que adormece o sujeito e lhe impede de transcender uma dada ordem cotidiana estabelecida. Pretendemos ainda indicar que essa urgência narrativa se apresenta como uma estratégia eficiente para o alcance e a captação de leitores apressados. Não para distraí-los ou diverti-los, mas para sensibilizá-los, a partir da representação de estilos de vida acelerados, automatizados e envolvidos por uma atmosfera terrorífica, de mal-estar (como é o do protagonista de $O$ cheiro do ralo), sobre as angústias humanas deflagradas por formas de vida típicas de uma sociedade em que imperam os media e um capitalismo voraz. Capitalismo este que, abreviando a relação dos seres com o tempo e com o entorno para garantir o lucro mediante a produção e o consumo em grande escala, desencadeia, entre outras coisas, intensos estados de torpor mental, anula a ética, a solidariedade e a afetividade entre os homens, além de estimular a projeção de um egocentrismo que tangencia a perversão.

\section{O cheiro do ralo}

Narrada em primeira pessoa por um protagonista sem nome, a obra $O$ cheiro do ralo dá visibilidade a uma sequência de episódios referentes ao cotidiano desse narrador protagonista. Trata-se de um cotidiano monótono, rotineiro, desgastado pela repetição de ações e

\footnotetext{
${ }^{3}$ Refiro-me aos romances como os de Proust, Joyce, Woolf, Cortázar etc. Essas narrativas que, aprofundando-se na psicologia das personagens ou explorando ao máximo grau fragmentos de realidades, carregavam-se de detalhes e se revestiam de uma linguagem complexa exigindo que o leitor, para compreender e desfrutar da leitura, travasse uma relação morosa com o tempo e percebesse o imperceptível, o incaptável, em um transcurso cotidiano acelerado.
} 
de fatos. Pouquíssimas são as alterações ou novidades registradas no dia a dia desse protagonista que, mesmo narrando sua própria existência, tem seus contornos psíquicos e físicos bastante rarefeitos. Ele quase não fala de si. Poucas vezes expressa pensamentos, opiniões e percepções. Demonstra não querer estabelecer laços humanos duradouros. Rompe com a namorada, por exemplo, para evitar o casamento, uma forma de relacionamento, por convenção, mais durável. Além disso, parece beirar, em alguns aspectos, uma condição inerte. São constantes as vezes em que o relato sugere que ele não registra sinais vitais fortes, já que pouco recorda, não se dá conta de muitas ações que realiza e, como ele mesmo afirma, nem sonhar sonha: "Eu nunca sonho" (Mutarelli, 2011, p. 18).

O que dá corpo ao relato não são elucubrações, projeções, lembranças do protagonista, nem consistentes processos de caracterização física das personagens ou dos espaços por onde circulam, ${ }^{4}$ mas uma sequência de fatos ou ações que ocorrem em uma espécie de loja de compra de produtos usados, cujo proprietário é o próprio protagonista, em sua casa ou em um bar, onde ele seguidamente vai comer um lanche no intuito de apreciar a bunda de uma garçonete, a qual, fazendo alusão ao filme Citizen Kane, ele chama de Rosebud.

Essa sequência de fatos relatados corresponde, preponderantemente, à narração das compras que ele realiza em sua loja e, consequentemente, dos diálogos mínimos, enxutos, que ele trava com personagens desconhecidas, não familiares e, por isso, sempre identificadas como ele ou ela, que vão à loja movidas pela intenção de lhe vender algum objeto. Na loja, há um banheirinho, cujo ralo - que dá título à obra - cheira, constantemente, muito mal. ${ }^{5}$ Devido à falta de familiaridade e afinidade do protagonista com as personagens com as quais cotidianamente negocia, o mau cheiro exalado pelo ralo é também, como bem observam Yazlle e Gonçalves Neto (2014, p. 65), o "mote para sustentar a conversa entre o narrador e os clientes que procuram a loja".

\footnotetext{
${ }^{4}$ Esses conteúdos, se presentes no relato, poderiam originar uma impressão de conhecimento ou deslindamento psíquico e físico das personagens e tornariam lenta a experiência da leitura.

${ }^{5}$ É importante frisar que o cheiro, perturbando o protagonista e as demais personagens, tende, metaforicamente, a representar uma espécie de mal, de incômodo imaterial (por isso simbolizado pelo cheiro), decorrente (como um resíduo) de uma perversa condição humana gerada no interior de um ambiente social (materializado pela loja do protagonista) cujo imperativo é a satisfação própria e o lucro, só possíveis a partir da exploração extrema do outro.
} 
Pelos breves diálogos que o protagonista desenvolve com as personagens e pelas ações que realiza e concisamente relata, vão se consumando leves impressões sobre sua condição humana. Suas repetidas atitudes sugerem ser seu perfil o de um homem insensível em relação aos demais, despreocupado com a dor e as necessidades dos outros, avesso a vivências familiares e resistente à constituição de relações duradouras, seja com pessoas ou com objetos, conforme se pode observar em um fragmento em que ele relata uma relação sexual que tem com sua ex-noiva, após, repentinamente, determinar o fim da relação faltando um mês para o casamento:

Ela diz: Me possui. Eu te amo querido. Mesmo que você não me ame. Mesmo que haja uma vadia entre nós, vamos nos casar. Eu aceito. Eu aceito tudo. Eu deixo você vir por trás. Forço minha cara em sua bunda. Como se quisesse entrar.

Eu falei que te faria rastejar. Rasteje.

Ela levanta a saia e puxa de lado a calcinha. Afasta os lábios e mostra a grutinha.

É isso que você quer? É para isso que você dá valor?

Meu pau até dói de tão duro.

Ela começa a chorar. Mas não fecha a grutinha. Nem para de me convidar. Vem! Ela fala em soluços. Se é isso o que quer, vem, come. Esfrego minha cara e me melo. Quanto mais eu quero mais forte ela chora. E, mesmo antes de tirá-lo pra fora, o gozo não posso conter.

Aí então já não sinto mais nada.

Nada tem para me dar.

Ela chora e bate na minha cara.

Depois chora baixinho, fazendo aquela cara engraçada.

Vou ao banheirinho me limpar e, quando volto, a encontro no chão.

"A chorar, a chorar, a chorar."

Com os convites na gráfica.

É o que ouço quando ela sai (Mutarelli, 2011, p. 21-22).

O foco na ação, que é sobressaliente no fragmento e torna a narrativa altamente veloz, testemunha a ausência de sentimentos, de conflitos do narrador protagonista diante da condição de sofrimento do outro (da ex-namorada). Ele não fala de si, de suas reações interiores, porque, obviamente, não sente nem amor, nem piedade, nem medo, nem tristeza. As únicas e ligeiras sensações que registra é 
o brevíssimo prazer do gozo ("E, antes mesmo de tirá-lo pra fora, o gozo não posso conter. Aí então já não sinto mais nada") e certo desdém pela moça, como atestam as expressões "a chorar, a chorar, a chorar", "fazendo aquela cara engraçada" e "Nada tem para me dar". Na urgência narrativa decorrente da focalização absoluta do relato na ação, vê-se estampado o esvaziamento sentimental e afetivo do protagonista. Um esvaziamento que o coloca em condição propícia para registrar o que, retomando as ideias de Jameson (1996), poderíamos classificar de instantes de intensidade.

O que se destaca nele é, portanto, um ego exacerbado que o incita a se afirmar, a se sobrepor aos demais, a querer sempre tirar vantagens. Essa característica saliente no protagonista - a afirmação do eu por meio de uma espécie de perversidade - entra em confronto com outros traços que lhe são intrínsecos, como a ausência de nome próprio e a carência afetiva, particularidades que lhe outorgam um aspecto superficial enquanto sujeito. Assim, a contradição caracteriza o protagonista fazendo com que ele surja como uma subjetividade complexa, forte e rasa ao mesmo tempo. Rasa, porque, equivalentemente às demais personagens, não tem nome. Carece, ainda, de densidade afetiva, sentimental, emocional, o que o coisifica, o desumaniza. Forte, porque a lacuna formada pela ausência de afetos, de sentimentos, de emoções, é preenchida por uma espécie de razão prática (calculista) que, aliada a impulsos de ordem sexual, leva-o a se centrar na busca absoluta do prazer próprio, mesmo que isso implique a usurpação subjetiva ou física do outro ("Aí então já não sinto mais nada. Nada para me dar") e a desconsideração de qualquer valor ético, moral, familiar.

Não se alimentando por esses pressupostos, que consideram o outro, a alteridade, como força capaz de condicionar 6 e determinar a formação do eu, o protagonista encontra as condições adequadas para se constituir a partir de seus impulsos mais primitivos (de ordem mais animal que humana e social), para se autocentrar de forma exacerbada, o que lhe outorga uma dimensão perversa, porque, nesse processo de

\footnotetext{
${ }^{6}$ Se consideramos o outro não como meio de prazer, mas como pessoa humana com direitos e deveres equivalentes aos nossos, se consideramos sua dimensão afetiva, é natural que a busca de nossa satisfação seja condicionada pelo cuidado de não o machucar, de não explorá-lo, de exercer nossos direitos até onde começa o dele.
} 
autovalorização excessiva, o outro serve unicamente enquanto objeto de predação. Conforme sustenta Birman (2001, p. 180), na

manipulação do outro como técnica de existência para a individualidade, maneira privilegiada para a exaltação de si mesmo [...] para o sujeito não importam mais os afetos, mas a tomada do outro como objeto de predação e gozo, por meio do qual se enaltece e se glorifica.

É esse autocentramento absoluto decorrente da falência do afeto, da desconsideração do outro como ser humano apto a sentir que é sobressaliente no protagonista, como indicam algumas afirmações que ele faz em determinado momento a sua ex-noiva referindo-se à ela, à mãe dele e as pessoas em geral: "eu não gosto dela, eu não gosto de você, eu não gosto de ninguém" (Mutarelli, 2011, p. 19).

A tentativa de satisfação sexual é o que leva o protagonista a desenvolver, ainda, uma espécie de obsessão por uma garçonete que ele chama de Rosebud, sem se interessar pelo verdadeiro nome dela nem se importar com sua vida, sua condição social ou existencial. Seu interesse por ela é tão carnal que, em lugar de identificá-la como humana, ele, metonimicamente, refere-se a ela como bunda. O que lhe importa é a parte, o fragmento, o objeto de prazer, não o todo, a pessoa. Isso é o que se observa em muitos momentos em que ele, em lugar de recordar e desejar a garçonete, o ser humano enquanto totalidade, lembra (e expressa a lembrança com um linguajar cru) somente da parte do corpo da personagem capaz de lhe propiciar gozo via instinto: "Se essa bunda, se essa bunda fosse minha" (Mutarelli, 2011, p. 21); "Entro direto no banho. Fazendo um Flashback do Rabo" (Mutarelli, 2011, p. 29). Como se percebe, o que é escrito em maiúsculo e tem, portanto, importância e status de nome próprio para o narrador não é a pessoa, o ser humano, mas o Rabo, a parte do corpo que poderá lhe render instantes de prazer de ordem instintiva, a parte que ele pode predar para obter gozo instantâneo e fugaz.

Explorando e predando os outros em função de seus aspectos físicos capazes de excitarem-no, o protagonista se projeta, por um lado, como um ser coisificado, à medida que pouco sente, não se comove, não se impressiona, é insensível em relação à dor ou à alegria do outro. Tem exaltada, por outro lado, a dimensão instintiva, e essa é a força que o move, que determina suas efêmeras relações e o assemelha a um animal, cujo interesse 
canaliza-se totalmente para a dimensão do outro (do corpo) propensa a lhe dar prazer, como indica a vulgar terminologia Rabo usada, por ele, para se referir à garçonete. Para caracterizálo, faz-se necessário, assim, recorrer ao complexo oximoro animal coisificado. Sua bizarra condição, possível de ser traduzida somente a partir de um antagonismo que expressa uma natureza viva (animal) e inerte (coisa), exprime a deterioração do sujeito enquanto humano, enquanto ser dotado de sentimento, de sensibilidade, de emoções, ou seja, enquanto homem civilizado, moldado sob a força de pressupostos éticos, morais, afetivos. A contraditória e desumana natureza do protagonista sugere, então, que ele é produto do esfacelamento de um modelo de sociedade em que a ética, a moral, o afeto, a razão sensível já não são os fortes pilares que lhe dão sustentação.

\section{Foco no lucro: míngua do humano}

O esfacelamento desse modelo social que tende a desencadear a deterioração do sujeito mediante a míngua do afeto, do sentimento, sugere a narrativa, está atrelado a fatores de caráter econômicos. É em decorrência do tipo de trabalho que desempenha, o qual está fundamentado na busca do lucro excessivo, que o protagonista vai perdendo a capacidade de sentir. Conforme mencionado, ele se apresenta como uma espécie de agiota, que compra objetos dos mais variados tipos, não para uso próprio, mas para revenda ou troca. Consequentemente, ele não desenvolve qualquer relação com os objetos. O objetivo da compra é a aquisição de dinheiro. Além disso, ao canalizar todas suas atenções para a obtenção do lucro, a relação e o diálogo que o protagonista estabelece com as personagens que vêm até sua loja para lhe oferecer produtos são brevíssimos e friamente calculados. É o que fica evidenciado num momento da narrativa em que o protagonista desenvolve um minúsculo diálogo com uma moça que chega até a loja com o intuito de lhe vender algo:

Olha, você falou tudo. No meu trabalho, quando eu comecei eu tinha que ser forte. Eu tinha que ser frio. Porque eu compro as coisas dos outros, e tinha que oferecer o mínimo possível, para ter o meu lucro. 
E, no começo, eu ficava com pena das pessoas, mas eu não podia ter pena, senão eu nunca ia chegar onde eu cheguei. Então eu fui ficando mais frio.

E onde foi que o senhor chegou? Assim, sendo frio.

No inferno. De Dante, associo. Pior que fui da pena ao prazer.

E agora o senhor sente remorso?

Não. Acho que não (Mutarelli, 2011, p. 65).

Como o protagonista afirma, seu esfriamento, sua concomitante coisificação e animalização não são traços imanentes a sua condição humana. Houve momentos em que essas características não o definiam. No princípio de sua carreira profissional, ele tinha pena das pessoas. Ele vai adquirindo esses traços a partir do exercício de seu trabalho, o qual, como indica o fragmento, está atrelado a uma concepção de sucesso que faz do lucro, do acúmulo de rendas e de coisas materiais, os parâmetros de realização humana: "eu não podia ter pena, senão eu nunca ia chegar onde eu cheguei". Ou seja, se não se tornasse insensível não teria alcançado uma condição financeira que lhe permite ter apartamento, carro e guardar dinheiro, o que é bem visível ao longo da narrativa, pois, em muitos momentos, ele menciona que abre caixas repletas de notas.

O que vai sendo explicitado no relato é que, quando se associa a realização humana ao lucro, ao dinheiro, ao acúmulo de objetos materiais, o ser humano é deslocado a uma posição secundária, já que a realização de um indivíduo implica a exploração do outro. Exploração que, sendo necessária para o sucesso de uma pessoa ou de um grupo, vai se naturalizando e, consequentemente, tornando insensível, automatizando e coisificando aquele que explora, ao ponto de não sentir, não conseguir perceber o outro, mas se preocupar unicamente consigo: ou seja, tornar-se excessivamente narcísico, egocêntrico, tal como ocorre com o protagonista.

Ao ser questionado pela vendedora sobre sua condição e seu conceito de sucesso assimilados e não revisados por ele, como indica a indagação "E onde foi que o senhor chegou?", o protagonista parece transcender, por um momento, seu estado de torpor. Expressa um lampejo de consciência sobre o quão vazio, distorcido e perturbador pode ser esse modelo de vida que coloca no lucro o vetor ou a razão existencial. Pela raivosa expressão "No inferno", ele transparece desconfiança e inconformidade com sua "vida de 
sucesso", além de manifestar um estado de desequilíbrio, de perturbação. A indagação o convida à reflexão e ele percebe que seu conceito de realização é falho. No entanto, mostra-se tão automatizado ao ponto de não conseguir reagir, já que nem sabe se é capaz de sentir remorso, como bem indica sua afirmação "Acho que não". Sua sensibilidade encontra-se tão adormecida que seus lampejos de consciência não se mostram suficientes para que ele redefina seus conceitos e suas condutas.

A narrativa vai explicitando, assim, as consequências humanas resultantes da assimilação de uma ideologia que associa, de forma direta, a realização do homem ao êxito financeiro: que consequências seriam essas? Por um lado, a coisificação, a animalização, o egocentrismo predador de quem explora e a dificuldade de desautomatização, de transcendência dessa condição bizarra alimentada por uma ideia distorcida de realização que, em lugar de preencher, esvazia o ser e o perturba. Por outro, a exploração, a predação, de muitos seres humanos como alternativa para uma questionável satisfação de poucos ou de um único ser, como é o caso do protagonista.

Considerando o fato de que na obra é um único indivíduo - o protagonista - que, em nome do lucro, da ascensão financeira e material, preda uma legião de outros indivíduos, é possível perceber que a referida narrativa faz alusão à estrutura, à dinâmica de funcionamento, aos valores e aos efeitos para a humanidade de uma sociedade como a capitalista. Nesse modelo de sociedade, semelhante ao que se visualiza na obra $O$ cheiro do ralo, o lucro é o fundamento que rege a vida dos seres. Uma de suas regras operacionais, a qual auxilia na viabilização do êxito financeiro, coincide com a exploração de muitos por poucos. Os efeitos da aplicabilidade e da retroalimentação dessa regra, como se pode constatar diariamente através de notícias e de estudos e como bem representa a obra, são a perversão, o aumento dos quadros de perturbação, a mineralização do ser humano, a insatisfação constante de quem explora a miséria, em suas várias facetas, dos explorados. A obra sugere, então, que, em uma sociedade como a capitalista, as chances de realização humana são mínimas, uma vez que a grande promessa de sucesso (a conquista de uma boa condição financeira) estimula a exploração humana, o que pode levar legiões à miséria e 
desumanizar e animalizar os seres que exploram, causando-lhes mais problemas, torpor e transtornos que, propriamente, satisfação.

\section{O cheiro do ralo: simbologia do mal e/ou do mal-estar humano}

O alto teor de torpor e perturbação trazidos por uma dinâmica existencial pautada em uma ideia que correlaciona realização a êxito financeiro, a conquistas materiais, é também explicitado na obra pela dura resistência do protagonista em relação ao terrível mau cheiro exalado pelo ralo do banheirinho de sua loja. Mesmo incomodado pelo horrível e constante odor, que se espalha em consequência de uma avaria registrada no sifão, ele protela o conserto, pois seus interesses estão sempre centrados na realização de negócios, na ascensão financeira. Não que ele não sinta o cheiro; ele o sente constantemente. Menciona-o constantemente, ao avisar os clientes que o péssimo odor provém do ralo. Quando, em dado momento, decide chamar um encanador, resolve não levar o processo adiante porque o preço é, a seu ver, muito alto, e o conserto levaria muito tempo, já que o procedimento, segundo o encanador, era um pouco complicado, exigiria a quebra da parede. Prefere, num ato impensado, automatizado, fechar, ele mesmo, o orifício com cimento, não solucionando o problema, pois a cada descarga, não tendo para onde escoar, os dejetos voltam pelo vaso inundando o banheiro de fezes, urina e de um cheiro infernal.

O péssimo odor do ralo, que, incomodando o narrador protagonista, deveria levá-lo a interromper os negócios, alterar sua rotina ao menos por alguns momentos, não surte efeito diante do avançado estágio de torpor, mineralização e obsessão pelo lucro demonstrado pelo protagonista, conforme é possível constatar no seguinte trecho em que ele troca palavras sobre o insuportável cheiro com alguém que vem lhe oferecer um objeto:

Mas, antes de fechar a porta, solta: Aqui cheira a merda.

É o ralo.

Não. Não é não.

Claro que é. O cheiro vem do ralo.

Ele fecha a porta.

O cheiro vem de você. [...]

Quem usa esse banheirinho?

Eu. 


\section{Quem mais?}

Só eu.

Ele continua com o sorriso no rosto, solta:

E então, de onde vem o cheiro?

Quando percebo, estou vendo uma jarra vazia.

Ligo a TV.

Abro Paul Auster (Mutarelli, 2011, p. 18).

O cheiro, sendo constatado acentuadamente ("aqui cheira a merda") por todas as demais personagens, apresenta-se, na narrativa, como uma espécie de mal, necessário talvez para desautomatizar o protagonista, tirá-lo do profundo estado de torpor em que se encontra submergido. Mal, porque é incorpóreo e, sendo assim, o protagonista não consegue desfazer-se dele como se desfaz das pessoas e dos objetos. Sem materialidade, sem forma, o cheiro não encontra barreiras. Espalha-se não lhe dando alívio. Cresce na narrativa como um elemento que perturba e que tende a simbolizar, portanto, o malestar psíquico, emocional, espiritual, tão incorpóreo quanto o cheiro, que acomete o protagonista, mas que ele não faz qualquer esforço para solucionar. Como afeta todas as personagens, mas não mobiliza o protagonista anestesiado por sua rotina, o cheiro do ralo também funciona na narrativa como um elemento simbólico que reforça o alto e irreversível grau da coisificação do sujeito.

O estado de automatismo do protagonista é tão acentuado que, mesmo quando alertado sobre a origem do cheiro por outra personagem (“Quem usa esse banheirinho?”), alerta que poderia levá-lo a conectar o problema do cheiro à sua condição humana, a refletir sobre seu modo de existência, resiste a qualquer processo de meditação.

A presença constante do cheiro e a passiva acomodação do protagonista ao mau odor sugerem que formas de vida fundamentadas na busca obstinada pelo acúmulo material encortelham o indivíduo a uma rotina marcada pela repetição cotidiana de ações (sem reflexão), correspondendo, portanto, a modalidades existenciais nocivas ao homem. Prejudicam, porque induzem o ser a uma espécie de estagnação propulsora da reprodução - manutenção imutável - de condutas, de valores estabelecidos, os quais podem ser altamente desumanos, uma vez que levam à predação e ao descarte do outro como um dejeto. 
O insuportável cheiro exalado pelo ralo, sendo imaterial e irrefreável, simboliza os efeitos incontornáveis de uma existência restrita à valorização da condição corpórea do ser e das coisas materiais em detrimento do espírito: quais são esses efeitos? O vazio existencial oriundo do uso e descarte rápido de seres e objetos que, sendo também imaterial e apresentando-se como resíduo de uma existência predatória, incapaz de preencher o ser, semelhante ao cheiro podre do ralo, instala-se no indivíduo proporcionando-lhe um eterno incômodo, caso o oco, o ralo, subjetivo não for preenchido ou cuidado com atenção. $\mathrm{O}$ problema do ralo, que contamina o ambiente, simboliza, dessa forma, o problema do protagonista: o registro de uma saturação (imaterial) de vazio decorrente de uma vida que confere excessivo valor à matéria, a qual, perdendo rapidamente a função (tornando-se detrito descartável), não alimenta a dimensão espiritual do ser, causando-lhe mal-estar.

A velocidade da narrativa materializada pela ênfase na ação, a recorrência ao ralo como símbolo de uma vida repleta de vazios, e, por isso, incomodativa como o mau cheiro do ralo, apresentam-se, assim, como algumas estratégias do romance cuja função parece ser a de sensibilizar o leitor, apressado e automatizado como o protagonista, sobre o vazio (a falta de conteúdo subjetivo e espiritual) existencial de uma vida orientada por valores como o do lucro e do prazer momentâneo mediante a predação do outro.

\section{Do vazio à epifania}

Como se mencionou, o que caracteriza o protagonista é uma paradoxal espécie de subjetividade saturada e vazia. Saturada porque moldada sob a força da ânsia pelo lucro, o qual, para ser alcançado volumosamente, como atesta a obra, exige rápidas e contínuas ações de compras e vendas; ações que aceleram a existência daquele que negocia (protagonista) levando-o a ter que se relacionar de forma predatória e muito breve com os outros. Essa dinâmica existencial, ao requerer um ritmo vital frenético, satura o indivíduo, esgota-o. No entanto, também o esvazia, porque a brevidade das vivências nada deixa a não ser ausência de experiências.

Para representar esse vazio existencial, a narrativa "preenche-se" pelo não dito, que se faz visível no enxugamento das orações e em 
saltos temporais e espaciais que lhe são sobressalientes. É o que se vislumbra no fragmento a seguir, em que, do relato do fechamento de uma compra realizada pelo protagonista em sua loja, a narrativa passa a pôr em cena ações que ele realiza já em sua casa, como se nada tivesse ocorrido (nem interna nem externamente) ou nada ele tivesse percebido durante seu deslocamento da loja até sua residência:

Tiro as notas da gaveta e volto a trancá-la. Ele nem as confere.

Ele sorri chorando. Sol e chuva, casamento de viúva. Penso.

Ligo a Tv. Antes via o lixo de graça. Agora pago para ver (Mutarelli, 2011, p. 26).

O que indica a passagem do tempo na narrativa é o espaço em branco. Uma espécie de não dito ou silenciamento aliado à descrição de ações e objetos que aludem a uma mudança de espaço. Esse espaço em branco exprime o esvaziamento subjetivo do protagonista. Indica que ele não reflete sobre o que vive nem rememora o vivido. Para dar forma a esses lapsos subjetivos do protagonista, a narrativa apela ao não dito, ao silêncio; a míngua do sujeito é representada, dessa forma, por meio de um experimentalismo perigoso, uma estratégia última e arriscada, já que ela poderia acarretar a morte do romance por não ter o que contar. $O$ cheiro do ralo atesta, portanto, os esforços formais a que é submetido o gênero romanesco para seguir narrando em tempos em que as experiências narráveis se rarefazem à medida que o sujeito (enquanto potestade racional, entidade sensível e sentimental) vai minguando, automatizando-se, ao ser moldado sob os impulsos de uma sociedade como a capitalista que, associando a realização humana à obtenção do lucro, coloca o ser em um ritmo existencial frenético e provoca, assim, a míngua das relações humanas duradouras e afetivas: aquelas que poderiam render lembranças, engendrar planos, paixões e projeções.

Esse salto temporal e espacial, estratégia compositiva sobressaliente em $O$ cheiro do ralo, expressa formalmente uma espécie de distração mental típica do protagonista, a qual contribui para a proliferação de um estado de apatia que o impossibilita de projetar e de realizar ações não condizentes com as que reproduz cotidianamente e de forma automática em nome de um conceito de sucesso (a atividade de compra e venda na loja). Quando ele retoma a consciência, já está em outro espaço, em sua casa, olhando para uma jarra vazia. Nem terminou de vivenciar um fato, nem refletiu e pensou 
sobre ele, nem conheceu a pessoa com a qual troca rápidas palavras (conforme indica a brevidade das orações que traduzem o diálogo) e já está em outro ambiente. Como pouco reflete, pouco contempla, pouco observa e não estabelece relações duráveis, o protagonista se apresenta como um ser de esparsa memória, de pouca atividade imaginativa e reflexiva, repleto, porém, de lapsos mentais.

Conforme aponta Benjamin (2012), uma vivência só é processada, conservada, assimilada e convertida em experiência transmissível quando a pessoa, conectada com um coletivo, mergulha em seu íntimo, burila, revisa o vivido, revisita-o, aprecia-o. Sem esses exercícios mentais que só se consolidam quando o indivíduo desacelera, uma vez que se trata de uma prática que exige "um estado de distensão que se torna cada vez mais raro" (Benjamin, 2012, p. 204), a vivência se dissipa brevemente e, não podendo ser reaproveitada pelo sujeito, nem transmitida como experiência, esvazia o ser. Assim, para dar sequência à vida, preencher os instantes, o indivíduo passa a depender quase plenamente de sugestões, ordens, estímulos externos que o levam mais a espécies de reações que a ações propriamente ditas.

É o que ocorre com o protagonista de $O$ cheiro do ralo. Não se permitindo pensar nem operar fora da lógica do lucro; não analisando com cuidado e tempo o que vivencia; centrando os interesses em sua inalterada rotina asseguradora do que ele entende ser progresso material e via de obtenção do prazer rápido e fugaz, o protagonista "preenche-se" de lapsos mentais, anula-se enquanto sujeito, isto é, enquanto potestade responsável pela tomada de decisões, pela projeção de situações existenciais. Passa, consequentemente, a depender de estímulos externos para reagir. Precisa ver a jarra vazia para perceber que já está em casa, ligar a TV e abrir um livro. Dependendo de estímulos externos para agir, após cada breve vivência, como o próprio protagonista admite, "o que vem? O vazio" (Mutarelli, 2011, p. 29).

Retendo pouco do que vivencia, a solidão e o silêncio se tornam altamente inconvenientes ao protagonista. Ele tem dificuldade, por exemplo, para conviver com o tempo livre dos finais de semana, como é possível constatar na seguinte passagem em que ele relata sua rotina em um final de semana.

Coloco o pó. Ligo a cafeteira. Folheio os jornais. Me excito com os classificados. Sábado é um longo dia. Pior o domingo. 
Ninguém entra, ninguém sai. [...] Descongelo algo no microondas. Tento comer. Não sinto o sabor. Assisto TV. O vai e vem em close-up me lembra uma engrenagem. Caio no sono. Domingo. Acordo na sala. A engrenagem ainda trabalha. TV a cabo, 24 horas de entretenimento. Preparo o café. Como uma fatia de pão de forma (Mutarelli, 2011, p. 20).

O que se percebe no fragmento é a presença de um ser humano automatizado (nem gosto sente), sem vida espiritual, de pouca atividade mental. Um ser que, consequentemente, não sabe lidar com o tempo livre, porque, colonizado pela lógica do sucesso financeiro que rege seu trabalho e o induz a viver seus dias trocando poucas palavras com desconhecidos, com os quais nunca chega a firmar laços, registra um vazio de memória, de afeto, de recordações, e um déficit em seu potencial de projeção via imaginação. Assim, ele não consegue relacionar-se consigo mesmo, consultar suas experiências, sentir-se, decidir a partir do vivido, criar, ficando na dependência de opções externas, fornecidas também pelo mercado, para preencher seu tempo. Essas opções são visíveis, por um lado, na presença de utensílios domésticos (máquinas) como a cafeteira e o micro-ondas, que, para alimentá-lo, exigem-lhe um mínimo de esforço e criatividade e lhe recolocam na lógica do consumo. Mostram-se, por outro lado, nos programas televisivos de entretenimento e leitura rápida de notícias e classificados capazes, unicamente, de conferirem ao protagonista breves momentos de excitação, os quais não solucionam o vazio. Apenas o encobrem, distraindo, por momentos, sua mente que, sendo descontraída, permanece em estado de inércia, de passividade, mesmo que ele demonstre capacidade de reflexão. Como afirma Chaui (2006), o divertimento, a distração, não preenchem o ser. Anulam sua atividade mental, levando-o ao esvaziamento, à impotência. $O$ efeito do entretenimento como descanso, diz a autora, é "a hostilidade diante de tudo o que possa ser mais do que simples divertimento, que peça atividade, em vez de passividade" (Chaui, 2006, p. 28).

A existência do protagonista afina-se, assim, a formas de vida que seriam bem proeminentes na sociedade atual. Estilos existenciais que, segundo Maffesoli (2003), correspondem a um tipo de vida que "individual ou social, não passa de uma sucessão de presentes, uma coleção de instantes experimentados com intensidades diferentes". (Maffesoli, 2003, p. 56). Sendo assim, para não sucumbir à sensação do 
nada, o protagonista precisa sempre retornar à ação ("Coloco o pó. Ligo a cafeteira") e realizar, constante e velozmente, inúmeras atividades em um curto intervalo de tempo. Até seu repertório de leitura é composto por livros que materializam a aceleração de seu pensamento. Afirma ler e gostar muito das obras do escritor norte-americano Paul Auster, pois esse autor, diz o protagonista, "me deixa confuso. Ele escreve no ritmo que penso. Vertiginoso" (Mutarelli, 2011, p. 14).

Essa serie de vivências e de práticas que garantem, momentaneamente, o preenchimento interior do protagonista, ao serem rapidamente consumidas, o reposicionam no vazio. É o que se observa no fragmento que relata o momento em que ele consegue tocar na bunda da garçonete depois de desejá-la obsessivamente, e sente tristeza, porque ao realizar sua obsessão, fica desnorteado, sem objetivos, experimentando, com intensidade, o nada.

A bunda era o contraponto do ralo. Esse ralo a que eu mesmo dei vida. Esse ralo é para onde projetei o escuro que sou. [...] O ralo e a bunda, dois extremos. Dois buracos extremos. Um leva ao interno do ser, outro ao interno do mundo. Toda a carga que depositei nessa bunda, infelizmente, quando me refiro à carga depositada, é uma figura meramente psicológica. Essa bunda, que agora abraço, era a minha salvação. A bunda é, e sempre foi, o desejo, a busca de tentar alcançar o inatingível. Essa bunda era, enquanto impossível, enquanto alheia, o contraponto do ralo. Mas o que eu realmente buscava não estava ali. Tampouco em outro lugar. O que eu buscava era só a busca. Era só o buscar. E por isso agora já não há mais desejo, só o cansaço. Só o vazio.

Só a certeza do incerto. Agora é preciso encontrar algo novo, de preferência uma bunda nova, para acreditar. Uma nova bunda em que eu possa crer. Nessa bunda eu não creio mais. Não que ela minta, ou tenha um dia mentido, para mim. Não. O mentiroso sou eu.

Pronto, era isso que você tanto queria? [...]

Tá feliz? Tá satisfeito?

Não consigo dizer nada.

Você não gostou da minha bunda?

Nada digo. Permaneço agarrado. Tenho medo de me soltar. De largar e ser lançado no espaço. Tenho medo de ser puxado pelo ralo. 
E sem que eu possa me conter, choro feito um bebê. [...]

Eu ainda me agarro a ela. A essa bunda que tanto sonhei. [...] Imagino poder ver esta cena do alto, este retrato do patético, do patético dessa nossa miserável condição (Mutarelli, 2011, p. 170-172).

Essa passagem relata um momento de epifania reflexiva registrado pelo narrador. Já no final da obra, após ter acesso a seu objeto de desejo, ele se permite pensar, avaliar, e conclui algo sobre o seu conceito de progresso e sobre a realização de sua obsessão, do projeto que o levara todo dia à lanchonete, em lugar de olhar o ralo, de ceder a suas interpelações, de perceber que esse orifício, com seu mau cheiro, simbolizava seu deteriorável percurso ou modelo existencial: uma existência que, orientada pelas leis do material (sucesso financeiro) e da matéria (instinto sexual), semelhante aos dejetos do ralo, ao cheiro e ao destino final a eles dado, provocava incômodo e teria como ponto de chegada a queda, a não transcendência, o escurecimento interior, como indica a conclusão do protagonista explicitada na oração "Esse ralo é para onde projetei o escuro que sou".

O momento de epifania, de revelação, de tomada de consciência decorrente do fato de ele ter realizado sua obsessão, ou seja, ter conseguido apoderar-se da bunda mediante um pagamento (ele paga para a garçonete exibir seu corpo) não o realiza, não o preenche por muito tempo. Trata-se de uma meta vazia, já que não é do plano espiritual, imaterial, nem se trata de uma busca pautada em princípios éticos e sentimentais, capazes, portanto, de desencadear o estabelecimento de laços humanos mais duráveis, de promover a consumação do afeto. Sendo matéria venerada pelo fato de ser matéria, de ter uma forma e um tamanho atraente, uma vez tocada, a bunda despe-se de qualquer serventia ou valor. Além disso, testemunha a condição material, não transcendental do ser humano: "é o buraco que leva para o interior do ser". Um interior corpóreo, fisiológico, putrefato.

Após tocar a bunda, após satisfazer rapidamente um desejo de ordem carnal, sexual, o protagonista fica obrigado a conviver com a dor e o vazio oriundos do esfacelamento de seus objetivos (o contraponto do ralo, aquilo que não o levava ao fundo, à queda) e da ausência de qualquer rastro ou vestígio interno, como memória, sentimento. Ele tem medo de soltar a bunda, pois percebe que, com a 
concretização desse objetivo propulsor de um prazer altamente fugaz e deteriorável, não lhe sobra nada, a não ser a possibilidade de ser lançado no vácuo (de ser puxado pelo ralo) ou de engendrar, mesmo esgotado (cansado), outra meta promotora de uma realização altamente perecível. Além disso, toma consciência, como evidencia a assertiva "O mentiroso sou eu", de que as esperanças são criações psicológicas, de que não há sentido para a vida, de que existir é patético, é sinônimo de sofrimento. A constatação do protagonista, explicitada pelas conclusivas afirmações "Mas o que eu buscava não estava aí. Nem em outro lugar", indica que, ao depositar na conquista de objetos materiais (como faz na loja) e no instantâneo e volátil prazer físico ou sexual (como o proporcionado pelo contato com a bunda), o sentido da vida corresponde a uma alternativa incômoda e arriscada, pois ela submete o ser humano a intensos, rápidos e muito frequentes momentos de queda, que brotam da rápida oscilação subjetiva entre prazer intenso (e volátil) e vazio. E tal oscilação provoca esgotamento psíquico, uma vez que obriga o ser a se submeter a um interminável processo de redefinição de desejos e objetivos necessários para que ele não sucumba a esse nada que se instala após o pico de intensidade, como indicam as orações: “agora já não há mais desejo. Só o cansaço. Só o vazio".

Colocando em cena a imagem e as vivências de um protagonista altamente complexo (culto, esclarecido, já que conhece Paul Auster, Jorge Luis Borges, escuta músicas de Chico Buarque, mas, ao mesmo tempo, mineralizado, animalizado e passivo, porque rendido à logica do sistema), O cheiro do ralo explicita como pode ser bizarra e contraditória a condição humana engendrada no ventre de uma sociedade como a atual. Uma sociedade em que os valores humanos foram substituídos pelos do lucro, gerando veneração ao material e um desprezo potencial pelo outro; desprezo esse que é eficiente na arte de deflagrar uma onda intensa de egoísmo e egocentrismo. Esse bizarro homem, como expressa o protagonista, pode corresponder a um indivíduo culto, esclarecido, capaz de refletir, porque tem acesso ao conhecimento; mas também impotente, porque sua lucidez sobre a realidade, consumando-se pela constatação da ausência de um sentido último ("o que eu realmente buscava não estava ali. Tampouco em outro lugar") e redentor, não consegue encontrar força para transcender a perecível, desumanizadora e arbitrária ideia da realização existencial pautada no lucro. 
A desilusão do protagonista materializada pelo choro ("choro feito criança") expressa uma saga existencial falida. Falida porque o sujeito representado toma consciência da ineficácia do conceito de realização que pauta sua vida, mas não consegue extrair do repertório literário (Paul Auster), musical (Chico Buarque), cinematográfico (Cidadão Kane), dos media (jornais, revistas, televisão), nem da própria vida um saber que o convença a superar o mal-estar em que se encontra mergulhado. $\mathrm{O}$ que põe em evidência a obra e, por isso, provoca incômodo, é a angústia existencial passível de ser experimentada em uma sociedade como a contemporânea. Uma sociedade que substitui os valores humanos pelo lucro e não consegue gestar e sustentar um conhecimento perene e capaz de fundamentar de forma convincente a existência, uma vez que, tendo como base econômica o mercado das comunicações, tende a fazer do próprio conhecimento um artefato de mercado altamente perecível e incapaz de se instituir como verdade absoluta ou como um universal inquestionável. Nesse contexto, como sustenta Vattimo (1992), o que circula e é produzido são saberes que podem anular uns aos outros, forçando o indivíduo a ter que se render ao relativismo e à perecibilidade da verdade. Ao colocar em cena a trajetória existencial de um protagonista insatisfeito, esvaziado, angustiado, que, ao final do relato, toma consciência de que o parâmetro de ordem econômica que orientou sua existência e o levou a uma condição extremamente egoísta e egocêntrica é falho e de que não existe uma verdade única e última sobre a qual fundar o edifício da vida, a narrativa traz à baila as terríveis consequências humanas que uma sociedade como a atual pode originar.

Experimentando uma existência solitária, centrada em si e vazia que o induz à conclusão de que não existe um sentido redentor para a vida, restam ao protagonista o processo de busca ("o que eu buscava era só a busca") e a morte como doídas soluções. E é assim, como dor e cura, que ele experimenta a morte ao final da narrativa. Ela lhe causa dor, porque ele percebe que, não tendo nada para deixar ou transmitir de sua vida, morrer coincide com o fim de tudo. É alívio, porque, matando o trabalho da consciência, a morte soluciona a decepção oriunda do constante contato com o vazio. Nas palavras do protagonista:

A morte é dura. A morte cura. A morte cura e machuca. A morte dói. Eu sou dor. Dói. Dói muito. Tudo é dor. Tudo é dor no nada. 
[...] Caio. O caminho é a queda. A queda me traga. Como um ralo. O silêncio é a língua que eu falo. [...] Eu não quero ir. Mas o abismo me engole (Mutarelli, 2012, p. 179-180, grifo nosso).

Essas são as últimas palavras emitidas pelo narrador protagonista. Elas fecham a narrativa. São orações reveladoras, porque, como expõe Benjamin (2012), o instante da morte é um momento propício à realização de um balanço da vida e à transmissão de experiências passíveis de serem reaplicadas. $O$ protagonista de $O$ cheiro do ralo, com pesar, se dá conta de que tem muito pouco ou nada a transmitir, pois, como ele reconhece: "O silêncio é a língua que ele fala". Não tem muito para contar, porque sua vida, como atesta sua angustiante, veloz e lacônica (cheia de saltos temporais e espaciais) narrativa, constituiu-se a partir de momentos de intensidade deflagradores de dor e vazio, inadequados, portanto, à transmissão.

Na verdade, há muita dor e vazio para expressar. O problema é que a dor não é um saber digno de ser repassado e o vazio não pode ser transmitido: carece de conteúdo. Trata-se de uma dor intensa, como indica a repetição do termo (dor) no fragmento, a qual anuncia que é mínima a possibilidade de realização, de tranquilidade, em um meio que associa êxito financeiro a sucesso humano e em que as verdades têm curto prazo de validade. O percurso existencial de um indivíduo preso ao material é, sugere a narrativa, semelhante ao percorrido pelos perecíveis dejetos que escoam pelo ralo. Vislumbrando-se unicamente como matéria e reduzindo a totalidade dos seres e do mundo à sua dimensão corpórea, o homem e sua existência só poderão contar com um destino final: o mesmo percorrido pelos dejetos que pelo ralo escoam, o intranscendente centro da terra.

\section{Na falta de utopia: viva o processo!}

É fato que na narrativa $O$ cheiro do ralo não se constata a afirmação de uma alternativa, de uma verdade que preencha o vazio do ser. Como o próprio protagonista afirma, o sentido não está em lugar nenhum ("o que eu buscava não estava aí. Tampouco em outro lugar"). Fica sugerido, porém, que depositar as atenções na busca, no processo, pode resultar numa alternativa superior à degradante vivência intensa de momentos, pois, como percebe o protagonista no final da narrativa, o 
que ele "buscava era só a busca" (Mutarelli, 2012, p. 170). Mas, em que consistiria o cultivo do processo, ou seja, buscar a busca? Consistiria, indica o relato (já que a sugestão constitui-se por um dizer implícito), no cultivo daquilo que o protagonista não realiza, ou seja, daquilo que não é relatado: a vivência profunda dos fatos, o culto da elucubração, da rememoração, o estímulo à imaginação, o estabelecimento de relações fortes e duradouras, alternativas que, não sendo experimentadas pelo protagonista, proporcionam-lhe vazio e esgotamento, deixando-o a mercê das interpelações de um meio que incita o consumo, o entretenimento e relacionamentos rapidamente descartáveis.

Ao retomar, intertextualmente, elocubrações contidas em obras de Jorge Luis Borges, o narrador afirma que, quando se adquire algo, "com o tempo [...] ele seria algo mais, uma coisa" (Mutarelli, 2011, p. 173). Na sequência, também indica que, quando algo ainda não foi adquirido, não existe, sendo, portanto, capaz "de qualquer forma ou cor. [...] de alguma forma existe. Vivo. E continuará a viver, e a se expandir. Incessantemente" (Mutarelli, 2011, p. 173). Eis, então, uma microutopia, sugerida na obra, para os momentos em que o ser humano não vislumbra um sentido absolutamente convincente e seguro para fundamentar a vida: só o não ter pode preencher o sujeito. Conforme indicam as palavras do narrador protagonista, diante da inexistência de um sentido absoluto, a promessa, a projeção, o cultivo da imaginação ("e continuará a se expandir") e a prática da rememoração são as únicas e (talvez) últimas alternativas para evitar o esvaziamento, a esgotadora e intensa oscilação (preenchimento e esvaziamento) subjetiva.

Projeta-se, assim, desde o ambiente putrefato da narrativa, uma fagulha de esperança. Dela brilha uma última e particularizante alternativa para libertar o homem preso a um sistema em que a grande satisfação está imperativamente associada ao progresso financeiro e material. Trata-se de uma espécie de heterotopia, para retomar o pensamento de Vattimo (1992). Heterotopia, porque corresponderia a um processo individual e particular: o cultivo da memória, da imaginação, do exercício de elucubrar, de sonhar, mesmo (como dizia Nietzsche) quando se sabe que se sonha. E tais atividades, exigindo tempo para se delinearem, podem tirar o indivíduo da frenética corrida cotidiana orientada pela promessa da realização via acúmulo e gozo material. 
Por meio de um discurso minimalista, que torna a leitura veloz e serve perfeitamente para replicar, no plano da representação, formas de vida voláteis e propulsoras do esvaziamento do ser, a narrativa $O$ cheiro do ralo apresenta ao leitor a dureza e os bizarros (grotescos) efeitos existenciais deflagrados por uma sociedade de corte capitalista como a atual. Ao replicar a efêmera e bizarra existência do protagonista, o relato não materializa de forma clara e exata uma utopia. Sugere, porém, que formas de vida diferentes da encarnada pelo protagonista podem, ainda, gerar outras experiências humanas.

$O$ cheiro do ralo atesta, assim, que a expressão do feio, do perturbador, do bizarro, a sugestão de possíveis e indefinidos caminhos existenciais e a recorrência a um discurso literário sintético, minimalista, lacônico, são estratégias que permitem ao romance seguir narrando e denunciando os negativos efeitos humanos trazidos por uma sociedade como a capitalista, mesmo quando as soluções e as verdades parecem enfraquecidas e o público leitor impossibilitado de contemplar com tranquilidade universos ficcionais artificiosos.

Com essas estratégias, o romance tende a estabelecer comunicação com aquele leitor que, semelhante ao protagonista, tem sua vida cronometrada em função da fixação na conquista do lucro e do material. Vê-se, em $O$ cheiro do ralo, um exemplo de adaptação do gênero romance ao público apressado de seu tempo. Um esforço que João Cabral de Melo Neto (1971), ao falar da poesia na década de 1960, assinalava ser altamente necessário para a sobrevivência da literatura na era da imagem, da comunicação e da consumação de processos receptivos rápidos, decorrentes do frenético estilo de vida que ia se consumando.

O que se constata é que, mesmo em tempos em que a aceleração do fluir cronológico é a menina dos olhos e em que os processos de leitura, sendo caracterizados pela exigência de tempo, podem ter seu espaço limitado, a literatura encontra na voragem narrativa, na sugestão, na denúncia da bizarrice humana e social, uma alternativa para fisgar leitores e seguir lançando luz sobre mazelas do capitalismo. Essa é uma das tendências da atual narrativa brasileira: embora não aponte soluções de cunho abrangente e coletivizante para os dramas sociais e humanos preponderantes no momento, não se furta ao exercício crítico que exerce desde que esse gênero ganha projeção com os primórdios da modernidade. 


\section{Referências}

BENJAMIN, Walter (2012). O narrador. In: BENJAMIN, Walter. Obras escolhidas I: Magia e técnica, arte e política. 8. ed. São Paulo: Brasilense. p. 213-240.

BIRMAN, Joel (2001). O mal-estar na atualidade: a psicanálise e as novas formas de subjetivação. 3. ed. Rio de Janeiro: Civilização Brasileira.

CHAUI, Marilena (2006). Simulacro e poder: uma análise da mídia. São Paulo: Fundação Perseu Abramo.

JAMESON, Fredric (1996). Pós-modernismo: a lógica cultural do capitalismo tardio. São Paulo: Ática.

MAFFESOLI. Michel (2003). O instante eterno: o retorno do trágico nas sociedades pós-modernas. São Paulo: Zouk.

MELO NETO, João Cabral (1971). Da função moderna da poesia. In: NUNES, Benedito. João Cabral de Melo Neto: Nota biográfica, introdução crítica, antologia, bibliografia. Rio de Janeiro: Vozes.

MUTARELLI, Lourenço (2011). O cheiro do ralo. São Paulo: Companhia das Letras.

PELLEGRINI, Tânia (2008). Despropósitos: estudos de ficção brasileira contemporânea. São Paulo: Annablume; Fapesp.

VATTIMO, Gianni (1992). A sociedade transparente. Lisboa: Relógio D’água.

YAZLLE, Senise Camargo Lima; GONÇALVES NETO, Nefatalin (2014). O cheiro do ralo: a estética do fragmento. FronteiraZ, São Paulo, n. 13, p. 61-81, dez. Disponível em: <https:/ / bit.ly/2P95lTO>. Acesso em: 10 jan. 2018.

Recebido em 25 de junho de 2017.

Aprovado em 21 de janeiro de 2018.

\section{Nota:}

Este artigo é resultado de pesquisas desenvolvidas no projeto "Para além das fronteiras: aproximações entre narrativas latino-americanas contemporâneas", aprovado e financiado pelo Conselho Nacional de Desenvolvimento Científico e Tecnológico (CNPq). 


\section{resumo/abstract/resumen}

\section{A estratégia da urgência: considerações sobre $O$ cheiro do ralo, de Lourenço Mutarelli}

Ivana Ferigolo Melo

A narrativa $O$ cheiro do ralo, de Lourenço Mutarelli, apresenta como elemento formal sobressaliente uma urgência na maneira de contar, a qual se mostra responsável pela representação de formas de vida aceleradas e deflagradoras de um estado de torpor existencial que adormece o sujeito e lhe impede de transcender uma dada ordem cotidiana estabelecida. Reconhecendo a forte presença desse elemento estrutural na referida narrativa, busca-se, neste estudo, defender a hipótese de que ele se apresenta como um recurso formal eficiente para o alcance e a captação de leitores apressados. Não para distraí-los ou diverti-los, mas para sensibilizá-los, a partir da representação de estilos de vida acelerados, automatizados e envolvidos por uma atmosfera terrificante, de mal-estar (como é a do protagonista de $O$ cheiro do ralo), sobre as angústias humanas deflagradas por formas de vida típicas de uma sociedade em que imperam os media e um capitalismo voraz, que, abreviando a relação dos seres com o tempo e com o entorno para garantir o lucro mediante a produção e o consumo em grande escala, desencadeia, entre outras coisas, intensos estados de torpor mental, anula a ética, a solidariedade e a afetividade entre os homens, além de estimular a projeção de um egocentrismo que tangencia a perversão.

Palavras chave: Lourenço Mutarelli, literatura brasileira contemporânea, ficção, urgência.

\section{The strategy of urgency: considerations on the $O$ cheiro do ralo, by Lourenço Mutarelli}

Ivana Ferigolo Melo

One of the defining traits of Lourenço Mutarelli's text $O$ cheiro do ralo, is its narrative urgency. This urgency is responsible for the representation of accelerated and deflagrating life forms of state of existential torpor that numbs the subject and prevents him from transcending an established daily order. Recognizing the strong presence of this structural element in this narrative, we seek to defend the hypothesis that it presents itself as an efficient formal resource to reach hurried readers. Not to distract or amuse them, but to sensitize them to the representation of accelerated lifestyles, automated and surrounded by a terrifying atmosphere of malaise (as is the protagonist of $O$ cheiro do ralo), about the human anguishes triggered by life 
forms typical of a society where the media and a voracious capitalism prevail, which, abbreviating the relationship of human beings with time and with the environment to ensure profit through production and consumption in large scale, unleashes, among other things, intense states of mental torpor, cancels ethics, solidarity and affection among men, as well as stimulating the projection of an egocentrism that gets close to perversion.

Keywords: Lourenço Mutarelli, Brazilian contemporary literature, fiction, urgency.

\section{La estrategia de la urgencia: consideraciones sobre $O$ cheiro do ralo, de Lourenço Mutarelli}

Ivana Ferigolo Melo

La narrativa $O$ cheiro do ralo, de Lourenço Mutarelli, presenta como elemento formal sobresaliente una urgencia en la manera de contar, la cual se hace responsable por la representación de formas de vida aceleradas y causantes de un estado de aturdimiento existencial que impide al sujeto trascender su realidad inmediata. Reconociendo la fuerte presencia de ese elemento estructural en la referida narrativa, se busca, en este estudio, defender la hipótesis de que dicho elemento formal se presenta como un recurso eficiente para el alcance y la captación de lectores apresurados. No para distraerlos, sino para sensibilizarlos, a partir de la representación de formas de vida aceleradas, automatizadas y envueltas por una atmosfera terrorífica de malestar (como es la del protagonista de $O$ cheiro do ralo), sobre las angustias humanas ocasionadas por estilos de vida típicos de una sociedad donde predominan los medios de comunicación y un capitalismo voraz, que, abreviando la relación de los seres con el tiempo y con el entorno, producen, entre otras cosas, intensos estadios de aturdimiento mental, anulan la ética, la solidaridad y la afectividad entre los hombres, además de estimular la proyección de un egocentrismo muy cercano a la perversión.

Palabras clave: Lourenço Mutarelli, literatura brasileña contemporánea, ficción, urgencia. 